\title{
Pengaruh Budaya Organisasi dan Kepemimpinan terhadap Kinerja Pengurus Cabang Olahraga dan Prestasi Atlet KONI Riau
}

\author{
DESWITA SATRIA \\ Jurusan Manajemen Fakultas Ekononomi, STIE Prakarti Mulya \\ Jl. Arifin Ahmad, Sidomulyo, Marpoyan Damai, Pekanbaru \\ Email: deswitadewi82@yahoo.com Hp. 0811755577
}

\begin{abstract}
The purpose of this study is to analyze organizational culture and leadership of the sport branch Board and Athlete Performances and impact against KONI (Indonesian National Sport Committee) of Riau Province. The object of research is the Sport Branch Board members of KONI (Indonesian National Sport Committee) of Riau Province. Population in this study is the Sport Branch Board members of KONI of Riau province as many as 165, with a sample of 117 people, by using a formula Solvin. The type of data required in this research is primary data and secondary data. Primary data sources were obtained from the results of empirical research through deployment questionnaire to the Branch Board Sports, while the secondary data source authors were obtained in the form of ready-made include about organisational profile of KONI of Riau Province. Data collection methods used were interviews and questionnaires. Data analysis tools used in the study was a multiple linear regression analysis. Results from this study showed that: (1) There is a positive effect of the Cultural Organization (X1) on the performance variable (Y1) the coofficient 0,386 with sig $=0.002 \leq 0,05$; (2) there is a positive influence Leadership variable (X2) of the variable Cultural Organization (Y1) the coofficient 0,182 with sig $=0,038 \leq 0,05$; (3) there is a positive influence organizational culture variable (X1) to achievement athlete (Y2) the coefficient $0,252$ with sig $0,002,4)$. there is positive leadership variables (X2) on achievment athlete (Y2) the coefficient 0,287 with a value coofficient sig = $0,000 \leq 0,05$. there is a positive influence organizational culture variables (X1) to the achievement athlete (Y2) with sig $=0,000 \leq 0,05$. Cultural organizations are independent variables that influence is greater than the other independent variables. Coofficient determination or R-square is $79.04 \%$, while $20.96 \%$ is influenced by other variables outside the research. Suggestions for further research are to find out other variables that have a greater influence on the performance of government policy, and the development of school sports.
\end{abstract}

Keyword: organizational culture, leadership, performance

\section{PENDAHULUAN}

Dalam rangka mewujudkan
budaya organisasi yang cocok
diterapkan pada sebuah organisasi,
maka diperlukan adanya dukungan dan

partisipasi dari semua anggota yang ada dalam lingkup organisasi tersebut para anggota membentuk persepsi keseluruhan berdasarkan karakteristik budaya organisasi yang antara lain meliputi 
inovasi, kemantapan, kepedulian, orientasi hasil, perilaku pemimpin, orientasi tim, karakteristik tersebut terdapat dalam sebuah organisasi atau perusahaan mereka.

Salah satu faktor eksternal yang mempengaruhi kinerja karyawan adalah budaya organisasi. Budaya organisasi merupakan nilai-nilai yang berkembang dalam suatu organisasi, dimana nilai-nilai tersebut digunakan untuk mengarahkan perilaku anggotaanggota organisasi (Soedjono, 2005). Perilaku karyawan tersebut dipengaruhi oleh lingkungan tempat mereka bekerja yang dibentuk melalui budaya organisasi, di mana keberadaan budaya dalam suatu organisasi diharapkan akan meningkatkan kinerja.

Seharusnya, penilaian kinerja dikaitkan dengan budaya organisasi sehingga dapat digunakan sebagai alat untuk mengungkapkan seberapa baik karyawan berkinerja sesuai dengan budaya organisasi dimana saling bekerja sama didalamnya, sesuai firman Allah SWT:

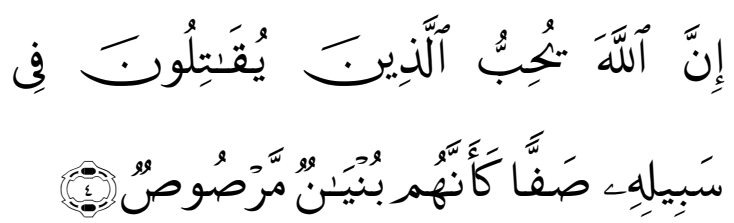

Artinya: "Sesungguhnya Allah menyukai orang yang berperang (berjuang) di jalan-Nya dalam barisan yang teratur seakanakan mereka seperti suatu banguanan yang tersusun kokoh". (QS. Al-Shaff, 61: 4).

Selanjutnya, sistem penilaian kinerja dapat membantu menemukan dan merumuskan aspek-aspek penting dari budaya dengan spesifikasi perilaku dan kompetensi yang diperhatikan untuk menyumbang keberhasilan organisasi, unit, kelompok, atau posisi.

Ditengah maraknya persaingan Prestasi olahraga, menuntut KONI (Komite Olahraga Nasional Indonesia) untuk lebih proaktif dalam melakukan pembinaan, baik melalui pembinaan kepengurusan di masing-masing cabang olahraga maupun pembinaan langsung terhadap atlet dan pelatih.

KONI (Komite Olahraga Nasional Indonesia) sebagai organisasi keolahragaan, sesuai dengan pasal 39 Undangundang Republik Indonesia Nomor 3 tahun 2005, tentang Sistem Keolahragaan Nasional mempunyai tugas: (a) Membantu Pemerintah Daerah dalam membuat kebijakan Daerah di bidang pengelolaan, pembinaan dan pengembangan olahraga prestasi; (b) Mengkoordinasikan induk organisasi cabang olahraga dan organisasi fungsional; (c) Melaksanakan pengelolaan, pembinaan dan pengembangan olahraga prestasi; dan (d) Menyiapkan, melaksanakan dan mengkoordinasikan keikutsertaan cabang olahraga prestasi dalam kegiatan olahraga yang bersifat lintas Daerah dan Nasional.

Tujuan pembinaan keolahragaan sebagaimana dimaksud Undang-undang Nomor 3 tahun 2005 tentang sistem Keolahragaan Nasional adalah memelihara dan menyehatkan, kebugaran, prestasi kualitas manusia, menanamkan nilai moral dan ahklak manusia, sportifitas, disiplin, mempererat dan membina persatuan dan kesatuan bangsa, memperkukuh ketahanan Nasional serta mengangkat harkat, martabat dan kehormatan Bangsa.

Sebagai Organisasi induk yang mengelola 47 cabang olahraga Prestasi maupun fungsional dibawah pembinaan KONI (Komite Olahraga Nasional Indonesia) Provinsi Riau belum sepenuhnya dapat merangkul semua cabang olahraga yang ada, terbukti dengan adanya beberapa cabang olahraga Prestasi yang tingkat perolehan medalinya masih dibawah target yang diharapkan, dengan demikian dukungan dan pembinaan 
secara menyeluruh harus ditingkatkan dengan bekerja sama melakukan koordinasi serta sosialisasi kesetiap cabang olahraga mengenai perencanaan program dan penyusunan target prestasi dalam setiap even kejuaraan, sehingga memudahkan dalam memonitor dan mengevaluasi kinerja pengurus cabang olahraga.

Meningkatkan prestasi olahraga merupakan target yang harus dicapai dengan adanya sikap disiplin dan motivasi yang tinggi dari atlet, pelatih dan pengurus cabang olahraga untuk melakukan latihan melalui sistem manajemen yang baik dengan memaksimalkan Sumber daya yang tersedia. Keberhasilan seorang atlet tidak lepas dari dukungan para pelatih yang lebih memahami kemampuan dan potensi yang dimiliki atletnya. Dalam memberikan pelatihan seorang pelatih harus memahami psikologi atlet dengan mengetahui latar belakang, kepribadian, kecerdasan emosional serta tingkat sosialisasi dengan lingkungan terutama untuk cabang olahraga beregu para atlet harus bisa bekerjasama dan menjaga kekompakan sesama tim.

Suatu prestasi olahraga tidak serta merta datang dengan sendirinya. Hal ini tidak semua orang bisa memahami, bahkan mereka hanya berorientasi pada hasil kompetisi atau kejuaraan yang di tandai dengan perolehan medali, tanpa memperhatikan proses dari pembinaan yang dimulai dari usia dini. Oleh karena itu, diperlukan kerjasama dengan lembaga-lembaga pengembangan IPTEK olahraga, untuk memberikan jawaban yang ilmiah dan nyata bahwa prestasi merupakan hasil dari proses latihan dan pengembangan bakat.

KONI (Komite Olahraga Nasional Indonesia) Provinsi Riau adalah sebuah organisasi yang bertugas membantu pemerintah dalam pengembangan olahraga dimana anggaran kegiatannya merupakan dana hibah dari Pemerintah Provinsi Riau karena selama ini masih minimnya dukungan dana dari Pihak Swasta maupun pelaku dunia usaha dalam pengembangan olahraga di Provinsi Riau, hal ini diduga bahwa KONI (Komite Olahraga Nasional Indonesia) beserta Pengurus cabang olahraga yang ada belum mampu menjaring "Bapak angkat" untuk ikut andil dalam peningkatan dan pembinaan prestasi, dengan demikian diharapkan agar Pimpinan organisasi harus mempunyai visi yang kuat dan mampu mensosialisasikan rencana KONI (Komite Olahraga Nasional Indonesia) serta menjalin kerjasama dengan Pihak swasta untuk peningkatan prestasi Olahraga di Provinsi Riau.

\section{LANDASAN TEORI \\ Budaya Organisasi}

Fungsi organisasi dalam membina dan mengembangkan kegiatan olahraga nasional mulai dari lingkup klub sebagai lapisan terbawah sampai ke tingkat Pengurus Besar sebagai lapisan teratas merupakan suatu "Conditio sine qua none" atau suatu keharusan yang mutlak keberadaannya. Lebih dari itu telah disadari semua pihak bahwa organisasi itu sebagai struktur dan proses yang tidak mungkin lagi ditangani secara amatiran, namun harus dikelola oleh orang-orang yang profesional.

Jika dilihat dari berbagai teori manajemen terinventarisasi fungsifungsi manajemen sebagai berikut: Planning, Organizing, Coordinating, Motivating, Controlling, Directing, Staffing, Innovation, Representation, Supervising, Communicating, Actuating, Appraising, Commanding, Reporting, Executing, dan Budgeting. Dari sekian banyak fungsi, ada yang memasukkan 
coordinating sebagai bagian essensial dari organizing, sedangkan communicating ada yang memasukkannya ke dalam motivating, dan reporting hanya sebagai alat kontrol semata bukan merupakan fungsi yang terpisah.

Keberhasilan suatu organisasi olahraga prestasi selalu dikaitkan dengan seberapa jauh prestasi olahragawan yang dihasilkan oleh organisasi tersebut. Secara teoritis dapat dikatakan bahwa organisasi olahraga prestasi yang dapat menjalankan fungsi-fungsi manajemen dengan baik dapat diharapkan akan menghasilkan prestasi yang baik pula.

\section{Kepemimpinan}

Dalam buku the art of leadership, ordway Tead menyatakan bahwa kepemimpinan adalah kegiatan mempengaruhi orang agar mereka mau bekerja sama untuk mencapai tujuan yang diinginkan (Kartono, Kartini, 2011: 57).

Dalam mengelola dan mengendalikan berbagai fungsi subsistem dalam organisasi agar tetap konsisten dengan tujuan organisasi dibutuhkan seorang pemimpin karena pemimpin merupakan bagian penting dalam peningkatan kinerja para pekerja. Pemimpin memiliki dampak yang signifikan terhadap sikap karyawan. Efektivitas seorang pemimpin akan sangat dipengaruhi oleh karakteristik bawahannya. Perilaku pemimpin pada dasarnya terkait dengan proses pertukaran yang terjadi antara pemimpin dan bawahannya. Kepemimpinan merupakan hubungan antara seseorang dengan orang lain, pemimpin mampu mempengaruhi orang lain agar bersedia bekerja bersama-sama dalam tugas yang berkaitan untuk mencapai tujuan yang diinginkan.
Pengaruh kepemimpinan terhadap kinerja didukung oleh beberapa penelitian sebelumnya yang dilakukan oleh Suharto (2005) yang meneliti pengaruh budaya organisasi, kepemimpinan dan motivasi kerja terhadap kinerja pegawai sumber daya manusia di Sekretariat DPRD Provinsi Jawa Tengah. Hasil penelitiannya menyebutkan bahwa terdapat pengaruh yang signifikan pada budaya organisasi, kepemimpinan, dan motivasi kerja terhadap kinerja.

Dalam dunia olahraga peran pemimpin sangat penting, hal ini perlu menjadi perhatian para pembina olahraga di Indonesia. Atlet serta pelatih yang telah mengakhiri tugasnya di dalam bidang keolahragaan harus tetap dapat hidup di tengah masyarakat. Bahkan jika mungkin, mereka yang telah memiliki jasa membawa nama bangsa dan negara di berbagai gelanggang olahraga perlu memperoleh penghargaan khusus yang dapat memberikan jaminan hidup bagi mereka. Tanpa adanya arah hidup yang jelas dan motivasi sesuai karirnya sebagai atlet atau pelatih, seorang olahragawan atau pelatih akan senantiasa dihantui rasa tidak aman untuk menghadapi masa depannya.

\section{Kinerja}

Hasibuan mengemukakan "kinerja (prestasi kerja) adalah suatu hasil kerja yang dicapai seseorang dalam melaksanakan tugas tugas yang dibebankan kepadanya yang didasarkan atas kecakapan, pengalaman dan kesungguhan serta waktu" (Hasibuan, Malayu S.P., 2001:34).

Kinerja selain dipengaruhi oleh faktor lingkungan juga sangat tergantung dari karakteristik individu seperti kemampuan, pengetahuan, keterampilan, motivasi, norma dan nilai. Dalam kaitannya dengan konsep 
kinerja, terlihat bahwa karakteristik individu seperti kepribadian, umur dan jenis kelamin, tingkat pendidikan suku bangsa, keadaan sosial ekonomi, pengalaman terhadap keadaan yang lalu, akan menentukan perilaku kerja dan produktivitas kerja, baik individu maupun organisasi sehingga hal tersebut akan menimbulkan kepuasan bagi pelanggan atau pasien. Karakteristik individu selain dipengaruhi oleh lingkungan, juga dipengaruhi oleh: (1) karakteristik organisasi seperti reward system, seleksi dan pelatihan, struktur organisasi, visi dan misi organisasi serta kepemimpinan; dan (2) karakteristik pekerjaan, seperti deskripsi pekerjaan, desain pekerjaan dan jadwal kerja.

\section{METODE PENELITIAN}

Penelitian ini menggunakan metode survey dengan pendekatan penelitian kuantitatif. Penelitian survei yang di maksud adalah bersifat menjelaskan hubungan kausal dan pengujian hipotesis. Menurut Sugiyono (2005:80) metode survei adalah penelitian yang dilakukan pada populasi besar maupun kecil, tetapi data yang dipelajari adalah data dari sampel yang diambil dari populasi untuk mengkaji populasi yang besar maupun yang kecil dengan menyeleksi serta mengkaji sampel yang di pilih dari populasi untuk menemukan tendensi, distribusi, dan interelasi relatif dari variabel-variabel penelitian.

$$
\text { Data dan informasi yang }
$$
dihasilkan dapat digunakan untuk membuat taksiran yang akurat mengenai karateristik keseluruhan populasi sehingga di mungkinkan tercapai deskripsi dari masing-masing variabel penelitian serta pengaruh antara masing-masing variabel, yang dalam penelitian ini adalah pengaruh Budaya Organisasi, Kepemimpinan dan
Kinerja Pengprov Cabor serta dampaknya terhadap Prestasi Atlet KONI (Komite Olahraga Nasional Indonesia) Provinsi Riau. Untuk mengetahui pengaruh antar variabel tersebut digunakan teknik analisis jalur (Path Analysis).

Teknik skorsing yang digunakan dalam penelitian ini adalah dengan skor minimal 1 dan maksimal 5, maka perhitungan indeks jawaban responden dengan rumus berikut :

Nilai indeks $=\{(\% \mathrm{f} 1 \times 1)+\{(\% \mathrm{f} 2 \times$ $2)+\{(\% 13 \times 3)+\{(\% \mathrm{f} 4 \times \quad 4)+\{(\% \mathrm{f} 5 \times$ 5) $\} / 5$

\section{Dimana :}

f1 : adalah frekuensi responden yang menjawab 1 dari skor yang digunakan dalam daftar pertanyaan kuisioner.

f2 : adalah adalah frekuensi responden yang menjawab 2 dari skor yang digunakan dalam daftar pertanyaan kuisioner.

f3 : adalah frekuensi responden yang menjawab 3 dari skor yang digunakan dalam daftar pertanyaan kuisioner.

f4 : adalah frekuensi responden yang menjawab 4 dari skor yang digunakan dalam daftar pertanyaan kuisioner.

f5 : adalah frekuensi responden yang menjawab 5 dari skor yang digunakan dalam daftar pertanyaan kuisioner.

Oleh sebab itu, angka jawaban responden tidak dimulai dari nol, tetapi dimulai dari angka 1 untuk minimal dan maksimal adalah 5, menggunakan kriteria 3 kotak (There box method). Maka interval yang diperoleh (menurut ferdinant, 2006:202) angka indeks terendah diperoleh jika semua responden (117 responden) menjawab pilihan jawaban dengan skor 1, dengan perhitungan menjadi : 
Nilai indeks terendah $=\{(117 \mathrm{X} 1)+(0 \mathrm{X}$

$\left.2)+\left(\begin{array}{lll}0 & X & 3\end{array}\right)+\left(\begin{array}{lll}0 & X & 4\end{array}\right)+\left(\begin{array}{lll}0 & X & 5\end{array}\right)\right\} / 117$

$=117 / 117=1$

Nilai indeks tinggi $=\{(0 \times 1)+(0 \times 2)+($

$\left.\begin{array}{lll}0 & \mathrm{X} & 3\end{array}\right)+\left(\begin{array}{lll}0 & \mathrm{X} & 4\end{array}\right)+\left(\begin{array}{llll}117 & \mathrm{X} & 5\end{array}\right) / 5$ $=358 / 117=5$

Menurut Riduwan dan Sunarto (2007:101) kaidah pengujian signifikansi jika Fhitung $\geq$ Ftabel, maka tolak Ho artinya signifikan dan Fhitung $\leq$ Ftabel, maka terima Ho artinya tidak signifikan. Besar hubungan atau korelasi antara variabel $\mathrm{X}$ dan Variabel $\mathrm{Y}$ ialah " $\mathrm{r}$ ", artinya hubungan kedua variabel tersebut sebagaimana kriteria angka korelasi tersebut adalah sebagai berikut :

Tabel 1

Intreprestasi Koefisien Korelasi Nilai r (Riduwan \& Sunarto, 2007:81)

\begin{tabular}{lc}
\hline \multicolumn{1}{c}{ Interval Koefisien } & Tingkat hubungan \\
\hline $0,80-1,000$ & Sangat kuat \\
\hline $0,60-0,799$ & Kuat \\
\hline $0,40-0,599$ & Cukup kuat \\
\hline $0,20-0,399$ & Rendah \\
\hline $0,00-0,199$ & Sangat Rendah \\
\hline
\end{tabular}

\section{HASIL}

Pengujian Hipotesis adalah suatu prosedur yang dilakukan dengan tujuan memutuskan apakah menerima atau menolak hipotesis mengenai parameter populasi. Berdasarkan hasil perhitungan secara keseluruhan variabel X1, dan X2 terhadap variabel maka akan diuraikan lebih lanjut.

Pada hipotesis pertama, Koefisien jalur diuji dengan uji t dengan derajat bebas 2 pada titik kritis 1.9805 .

Ho: $\beta$ X1Y1 = 0

Ha: $\beta$ X1Y1 $\neq 0$

Kemudian didapatkan nilai $\mathrm{t}=$ 4,503 >1.9805, dengan demikian Ho ditolak. Hal ini berarti variabel Budaya Organisasi (X1) memiliki pengaruh secara parsial terhadap kinerja Pengprov cabor (Y1). Ini berarti bahwa budaya organisasi berpengaruh positif dan signifikan terhadap kinerja Pengprov Cabor (Y1). Hal ini berdasarkan nilai sig pada tabel yang memperlihatkan bahwa nilai sig variabel Budaya Organisasi (X1) terhadap variabel kinerja Pengprov Cabor (Y1) sebesar 0,000. Artinya pengaruh Budaya Organisasi (X1) terhadap kinerja pengprov Cabor (Y1) cukup kuat, dengan kontribusi variabel $\mathrm{X} 1$ terhadap $\mathrm{Y} 1$ dengan tingkat signifikansinya 0,000 atau $\leq 0,05$ sehingga Ho ditolak. Hal ini diartikan bahwa terdapat pengaruh positif dan signifikan antara Budaya Organisasi (X1) terhadap Kinerja Pengprov cabor (Y1).

Pada hipotesis kedua, Koefisien jalur diuji dengan uji t dengan derajat bebas 2 pada titik kritis 1.9805 .

Ho: $\beta$ X2Y1 = 0

Ha: $\beta$ X2Y $1 \neq 0$

Kemudian didapatkan nilai $\mathrm{t}=$ 2,098 > 1.9805 dengan demikian Ho ditolak. Hal ini berarti secara parsial variabel Kepemimpinan (X2) memiliki pengaruh secara parsial terhadap kinerja Pengprov cabor (Y1). Ini berarti bahwa Kepemimpinan (X2) berpengaruh positif dan signifikan terhadap kinerja Pengprov cabor (Y1). Hal ini berdasarkan nilai sig pada tabel 4.11 yang memperlihatkan bahwa nilai sig variabel Kepemimpinan (X2) terhadap variabel kinerja Pengprov 
cabor (Y1) sebesar 0,038. Artinya pengaruh Kepemimpinan (X2) terhadap kinerja Pengprov Cabor (Y1) cukup kuat, dengan kontribusi variabel X2 terhadap Y1 dengan tingkat signifikansinya 0,038 atau $\leq 0,05$ sehingga Ho ditolak. Hal ini diartikan bahwa terdapat pengaruh positif dan signifikan antara Kepemimpinan (X2) terhadap kinerja Pengprov Cabor (Y1).

Pada hipotesis ketiga, koefisien jalur diuji dengan uji t dengan derajat bebas 2 pada titik kritis 1.9805 .

$$
\begin{aligned}
& \text { Ho: } \beta \text { X1Y2 }=0 \\
& \text { Ha: } \beta \text { X1Y2 } \neq 0
\end{aligned}
$$

Kemudian didapatkan nilai $\mathrm{t}=$ 3,134 > 1.9805 dengan demikian Ho ditolak. Hal ini berarti secara parsial variabel Budaya Organisasi (X1) memiliki pengaruh secara parsial terhadap Prestasi Atlet (Y2). Ini berarti bahwa Budaya Organisasi (X1) berpengaruh positif dan signifikan terhadap Prestasi Atlet (Y2). Hal ini berdasarkan nilai sig pada tabel 4.14 yang memperlihatkan bahwa nilai sig variabel Budaya Organisasi (X1) terhadap variabel Prestasi atlet (Y2) sebesar 0,002. Artinya pengaruh Budaya Organisasi (X1) terhadap Prestasi Atlet (Y2) cukup kuat, dengan kontribusi variabel $\mathrm{X} 1$ terhadap $\mathrm{Y} 2$ dengan tingkat signifikansinya 0,002 atau $\leq 0,05$ sehingga Ho ditolak. Hal ini diartikan bahwa terdapat pengaruh positif dan signifikan antara Budaya Organisasi (X1) terhadap Prestasi Atlet (Y2).

Pada hipotesis keempat, koefisien jalur diuji dengan uji t dengan derajat bebas 2 pada titik kritis 1.9805 .

Ho: $\beta$ X2Y2 $=0$

Ha: $\beta$ X2Y $2 \neq 0$

Kemudian didapatkan nilai $\mathrm{t}=$ 3,752 > 1.9805 dengan demikian Ho ditolak. Hal ini berarti secara parsial variabel Kepemimpinan (X2) memiliki pengaruh secara parsial terhadap Prestasi atlet (Y2). Ini berarti bahwa variabel Kepemimpinan (X2) berpengaruh positif dan signifikan terhadap pencapaian Prestasi atlet (Y2). Hal ini berdasarkan nilai sig pada tabel 4.14 yang memperlihatkan bahwa nilai sig variabel Kepemimpinan (X2) terhadap variabel Prestasi atlet (Y2) sebesar 0,000. Artinya pengaruh Kepemimpinan (X2) terhadap pencapaian target prestasi atlet (Y2) cukup kuat, dengan kontribusi variabel X2 terhadap Y2 dengan tingkat signifikansinya 0,000 atau $\leq 0,05$ sehingga Ho ditolak. Hal ini diartikan bahwa terdapat pengaruh positif dan signifikan antara Kepemimpinan (X1) terhadap pencapaian Prestasi atlet (Y2).

Pada hipotesis kelima, koefisien jalur diuji dengan uji t dengan derajat bebas 2 pada titik kritis 1.9805 .

Ho: $\beta \mathrm{Y} 1 \mathrm{Y} 2=0$

На: $\beta$ Y1Y2 $\neq 0$

Kemudian didapatkan nilai $\mathrm{t}=$ 5,153 > 1.9805 dengan demikian Ho ditolak. Hal ini berarti secara parsial variabel Kinerja Pengprov Cabor (Y1) memiliki pengaruh terhadap pencapaian target Prestasi atlet (Y2). Ini berarti bahwa Kinerja Pengprov cabor (Y1) berpengaruh positif dan signifikan terhadap pencapaian Prestasi atlet (Y2). Hal ini berdasarkan nilai sig pada tabel 4.14 yang memperlihatkan bahwa nilai sig variabel Kinerja Pengprov Cabor (Y1) terhadap variabel Prestasi atlet (Y2) sebesar 0,392. Artinya pengaruh Kinerja Pengprov cabor (Y1) terhadap pencapaian target prestasi atlet (Y2) cukup kuat, dengan kontribusi variabel Y1 terhadap Y2 dengan tingkat signifikansinya 0,000 atau $\leq 0,05$ sehingga Ho ditolak. Hal ini diartikan bahwa terdapat pengaruh positif dan signifikan antara Kinerja Pengurus Cabang Olahraga (Y1) terhadap pencapaian Prestasi atlet (Y2). 


\section{PEMBAHASAN}

Pengaruh Langsung Variabel Budaya Organisasi (X1) terhadap Variabel Kinerja Pengprov Cabor (Y1)

Dari hasil perhitungan secara statistik menunjukkan dengan nilai koefisien jalur sebesar 0,400 nilai $t$ hitung yang diperoleh sebesar 4,503 lebih besar dibandingkan $t$ tabel sebesar 1.9805.

Hal ini menunjukkan bahwa variabel Budaya Organisasi (X1) berpengaruh signifikan terhadap variabel Kinerja Pengprov Cabor (Y1). Hal ini karena Budaya Organisasi (X1) mempunyai pengaruh yang sangat besar dalam peningkatan prestasi melalui kinerja yang baik dan merupakan target utama dalam organisasi. KONI (Komite Olahraga Nasional Indonesia) merupakan organisasi olahraga bertugas membina dan mengembangkan olahraga di Provinsi Riau, harus mempunyai nilainilai dan norma yang mendukung kegiatan sebagai bentuk cerminan organisasi, dengan adanya budaya yang kuat akan membangun komitmen serta menuntun dan membentuk sikap perilaku terhadap sesuatu yang lebih besar dari pada kepentingan individu.

Hasil penelitian ini sejalan dengan hasil penelitian yang telah dilakukan oleh Dedi Mulyadi, Eman Sulaeman dan Aris Ramdani dimana hasil pengujian hipotesis di peroleh thitung sebesar 6,112 dan besar dari ttabel dengan nilai 1,6112 > 1,671. Hal ini berarti bahwa Ho di tolak yang menyatakan pengaruh budaya organisasi terhadap kinerja Pengprov Cabor adalah positif dan signifikan.

\footnotetext{
Pengaruh Langsung Variabel Kepemimpinan (X2) terhadap Variabel Kinerja Pengprov Cabor (Y1)
}

Dari hasil perhitungan secara statistik menunjukkan bahwa variabel Kepemimpinan (X2) berpengaruh signifikan terhadap kinerja Pengprov cabor (Y1), dengan nilai koefisien jalur sebesar 0,186 Nilai thitung yang diperoleh sebesar 2,098 lebih besar dibandingkan ttabel sebesar 1.9805, hal ini menunjukkan bahwa variabel Kepemimpinan (X2) berpengaruh signifikan terhadap variabel kinerja Pengprov cabor (Y1). Hasil ini diperkuat oleh teori kepribadian menurut Moejiono (2002) memandang bahwa kepemimpinan tersebut sebenarnya sebagai akibat pengaruh satu arah, karena pemimpin mungkin memiliki kualitas-kualitas tertentu yang membedakan dirinya dengan pengikutnya.

Dalam hal kepemimpinan ini lebih kepada visi misi yang ditetapkan sebelumnya, bagaimana seorang pemimpin mampu menggerakan bawahan dan bekerjasama dengan semua bidang untuk menetapkan standar kinerja.

Dalam berkomunikasi dengan anggota organisasi lainnya, lebih pada sistem pertukaran informasi mengenai perkembangan prestasi yang dikelola oleh masing-masing cabor secara berkesinambungan dan terus menerus. Untuk indeks terendah pada kepemimpinan, ini disebabkan oleh kesempatan bagi mantan atlet dan pelatih dalam memperoleh pekerjaan sangat minim sehingga berpengaruh terhadap motivasi dan semangat. Impikasinya adalah, jika indeks terendah tersebut tidak diperbaiki dan dikelola dengan lebih baik lagi, tentunya hal ini dapat mengganggu upaya peningkatan prestasi atlet kedepannya, karena ini juga menyangkut kesejahteraan pelaku olahraga. 


\section{Pengaruh Langsung Variabel Budaya Organisasi (X1) terhadap Variabel Prestasi Atlet (Y2)}

Dari hasil perhitungan secara statistik menunjukkan dengan nilai koefisien jalur sebesar 0,245 , nilai $t$ hitung yang diperoleh sebesar 3,134 lebih besar dibandingkan $t$ tabel sebesar 1.9805, hal ini menunjukkan bahwa variabel Budaya Organisasi (X1) berpengaruh signifikan terhadap variabel Prestasi Atlet (Y2).

\section{Pengaruh langsung Variabel Kepemimpinan (X2) terhadap variabel Prestasi atlet (Y2)}

Dari hasil perhitungan secara statistik menunjukkan dengan nilai koefisien jalur sebesar 0,276 , nilai $t$ hitung yang diperoleh sebesar 3,752 lebih besar dibandingkan $t$ tabel sebesar 1.9805.

Hal ini menunjukkan bahwa variable Kepemimpinan (X2) berpengaruh signifikan terhadap variabel Prestasi Atlet (Y2).

Pemimpin yang demokratis memposisikan setiap orang sebagai sosok yang penting dalam perjalanan kerja organisasi, pengaruh gaya kepemimpinan terhadap prestasi memang sangat menentukan tingkat keberhasilan program kerja, yang pada akhir hasilnya juga maksimal yaitu prestasi terbaik.

\section{Pengaruh Langsung Variabel Kinerja (Y1) terhadap Variabel Prestasi Atlet (Y2)}

Dari hasil perhitungan secara statistik menunjukkan dengan nilai koefisien jalur sebesar 0,392, nilai $t$ hitung yang diperoleh sebesar 5,153 lebih besar dibandingkan $t$ tabel sebesar 1.9805.

Hal ini menunjukkan bahwa variabel Kinerja (Y1) berpengaruh signifikan terhadap variabel Prestasi Atlet (Y2).

Berbagai permasalahan dalam pembinaan olahraganya sendiri di Indonesia menjadi rancu. Sebagian orang berpendapat bahwa atlet kurang termotivasi untuk berprestasi, karena ini juga di pengaruhi dari kinerja pengurus cabang olahraga, sehingga berbagai upaya diarahkan untuk meningkatkan motivasi atlet. pemberdayaan motivator belum juga dirasakan karena, pertama mungkin rumusan motivasi itu sendiri belum terlalu jelas seolah-olah dengan sekedar membangkitkan semangat juang, Kedua motivasi mungkin bukan satu-satunya faktor yang menjadi kendala bagi atlet untuk berprestasi, karena di dalam olahraga setidaknya sejumlah aspek seperti kognisi, emosi, dan perilaku, di samping motivasi memiliki peran yang sama pentingnya dalam mempengaruhi prestasi atlet. Ketiga, motivasi baik itu sifatnya intrinsik maupun ekstrinsik, harus terarah pada suatu sasaran tertentu. Karena, tanpa adanya sasaran tertentu, arah perilaku seseorang menjadi tidak jelas. Keempat, motivasi mengacu pada adanya kebutuhan seseorang yang dilandasi oleh kepribadian individu yang bersangkutan. Karenanya, motivasi tidak bisa digeneralisasikan bagi semua orang melainkan harus ditinjau secara khusus dari satu individu ke individu lainnya. Selanjutnya, motivasi dipengaruhi oleh berbagai faktor yang amat kompleks, termasuk di dalamnya intensitas atau besarnya tekanan (stress) yang menghambat seseorang untuk mengembangkan motivasinya. Keenam, aspek komunikasi antara atlet, pelatih dan pengurus berdampak signifikan untuk membangkitkan motivasi atlet untuk berprestasi. Ketujuh, peran berbagai pihak sangat diharapkan untuk meningkatkan kinerja pengurus cabang olahraga 
dalam melatih atlet agar berprestasi. Sebagai contoh, peningkatan kinerja olahraga melalui latihan imajeri, latihan konsentrasi dan upaya meningkatkan kinerja olahraga dengan meningkatkan rasa percaya diri. Kedelapan, berbagai fasilitas untuk mengatasi problematik psikologis atlet perlu diadakan, termasuk di antaranya program konseling dan upaya mengatasi kondisi "burn-out dan cedera fisik maupun psikis.

\section{Pengaruh tidak langsung variabel Budaya Organisasi (X1) terhadap Variabel Prestasi Atlet (Y2)}

Dari hasil analisis jalur bahwa variabel Budaya Organisasai (X1) mempengaruhi secara tidak langsung terhadap variable Prestasi atlet (Y2) melalui variabel kinerja (Y1) sebesar 0,157, sehingga dapat disimpulkan bahwa pengaruh tidak langsung lebih kecil dari pada pengaruh langsungnya. Hasil analisis menunjukkan bahwa pengaruh Budaya organisasi terhadap prestasi atlet melalui kinerja Pengpov cabor secara tidak langsung belum cukup untuk mendukung pengaruh Budaya organisasi terhadap prestasi atlet. Hal ini bisa dilihat pada hasil analisis jalur pengaruh Budaya organisasi terhadap prestasi atlet melalui variabel kinerja pengprov mengalami penurunan. Dengan demikian Budaya organisasi itu baru bisa meningkatkan pencapaian prestasi jika Budaya organisasi dirasakan mampu meningkatkan rasa kepedulian dan kebersamaan dalam pencapaian tujuan. Untuk itu organisasi harus lebih menanamkan rasa motivasi yang tinggi terhadap atlet dengan memberikan motivasi dan bantuan pembinaan khusus bagi atlet yang berprestasi.

\section{Pengaruh tidak langsung variabel Kepemimpinan (X2) terhadap variabel Prestasi Atlet (Y2)}

Dari hasil analisis path bahwa variabel kepemimpinan mempengaruhi secara tidak langsung terhadap variabel prestasi atlet (Y2) melalui variabel kinerja

Pengprov cabor (Y1) sebesar 0,073, sehingga dapat disimpulkan bahwa kepemimpinan memiliki pengaruh tidak langsung lebih kecil dari pada pengaruh langsungnya. Dari hasil analisis menunjukkan bahwa pengaruh kepemimpinan (X2) terhadap prestasi atlet (Y2) melalui kinerja Pengprov Cabor (Y1) yang diberikan kepada pengurus cabor, secara tidak langsung belum cukup untuk mendukung pengaruh kepemimpinan (X2) terhadap terhadap prestasi atlet (Y2) melalui variabel kinerja. Hal ini bisa dilihat pada hasil analisis jalur pengaruh kepemimpinan (X2) terhadap prestasi atlet (Y2) melalui variabel kinerja Pengprov cabor mengalami penurunan, dimana pengprov cabor merasakan secara tidak langsung kurang maksimalnya pengaruh kepemimpinan (X2) terhadap prestasi atlet (Y2) melalui variabel kinerja Pengprov. Dengan demikian pimpinan harus lebih bijaksana dan adil dalam memimpin, memberikan dukungan dalam bekerja, lingkungan kerja yang nyaman dan fasilitas yang sesuai dimana hal tersebut mampu menjadi motivasi pengprov cabor.

\section{Analisis Jalur (Path Analysis)}

Teknik analisis yang digunakan pada penelitian ini adalah analisis jalur (path analysis). Salah satu syarat yang harus dipenuhi dalam analisis jalur adalah bahwa data harus menunjukkan kenormalan. Kenormalan diterima jika titik-tikik data pada normal $p-p$ plot tersebar 
mendekati garis lurus yang membentuk sudut $45^{\circ}$.

Koefisien jalur adalah koefisien regresi baku (Standarized regression coefficient), yang menunjukkan pengaruh langsung variabel independen terhadap variabel dependen yang telah tersusun dalam diagram jalur.

Path analysis merupakan teknik yang digunakan untuk menganalisa hubungan sebab akibat yang inheren antar variabel yang disusun berdasarkan urutan temporer dengan menggunakan koefisien jalur sebagai besaran nilai dalam menentukan besarnya pengaruh variabel indenpenden exogeneous terhadap variabel dependen endogeneous (Sarwono, Jonathan, 2011).
Beberapa defenisi dalam analisis jalur (path analysis) : 1). Dalam path analysis hanya digunakan sebuah lambang variabel, yaitu $X$. Untuk membedakan $\mathrm{X}$ yang satu dengan $\mathrm{X}$ yang lainya digunakan Subcript (indeks), contohnya : X1, X2,X3 ... Xk. 2). Jenis variabel terbagi atas 2 yaitu variabel yang menjadi pengaruh (Exegenous variable) dan variabel yang dipengaruhi (enegenous variable). 3). Lambang hubungan langsung dari eksogen ke endogen adalah panah bermata satu, yang bersifat recursive atau arah hubungan yang tidak berbalik/satu arah. 4). Diagram jalur merupakan diagram atau gambar yang mensyaratkan hubungan terstruktur antar variabel (Al Rasyid, 2005: 41).

\section{Gambar 1}

\section{Diagram jalur yang menyatakan hubungan kausal dari X1,X2, ke Y1}

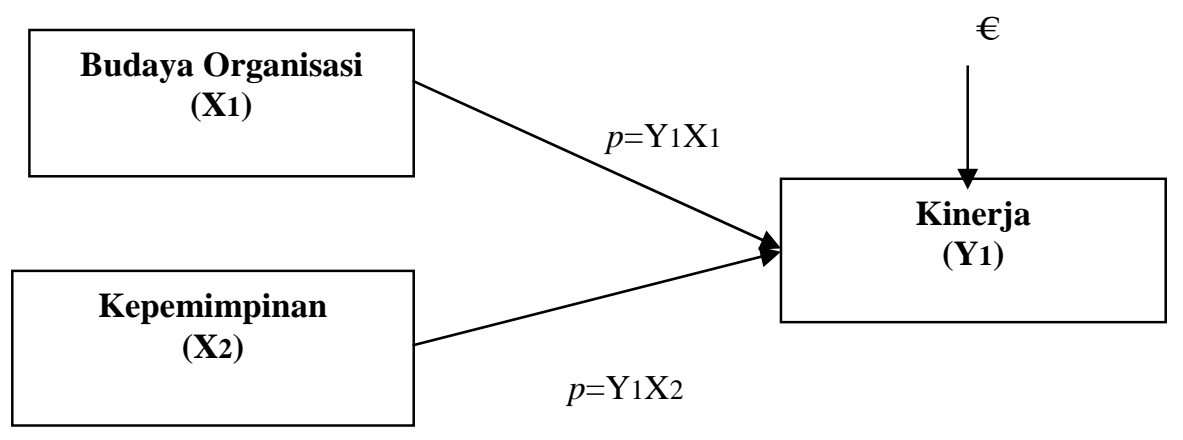

Gambar 1. memperlihatkan pengaruh $\mathrm{X} 1$, dan $\mathrm{X} 2$ ke $\mathrm{Y} 1$ adalah hubungan kausal. Besarnya pengaruh $\mathrm{X} 1$ ke Y1, dan X2 ke Y1, masing-masing dinyatakan oleh besarnya nilai numerik koefisien jalur $p \mathrm{Y} 1 \mathrm{X} 1$ dan $p \mathrm{Y} 1 \mathrm{X} 2$. Koefisien jalur $p \mathrm{Y} 1 \epsilon$ menggambarkan besarnya pengaruh langsung variable residu terhadap Y1. Bentuk persamaan strukturalnya adalah: 


\section{Gambar 2}

Diagram Jalur yang menyatakan Hubungan Kausal dari X1, X2, Y1, keY2

$\mathrm{Y} 1=p \mathrm{Y} 1 \mathrm{X} 1+p \mathrm{Y} 1 \mathrm{X} 2+\epsilon$

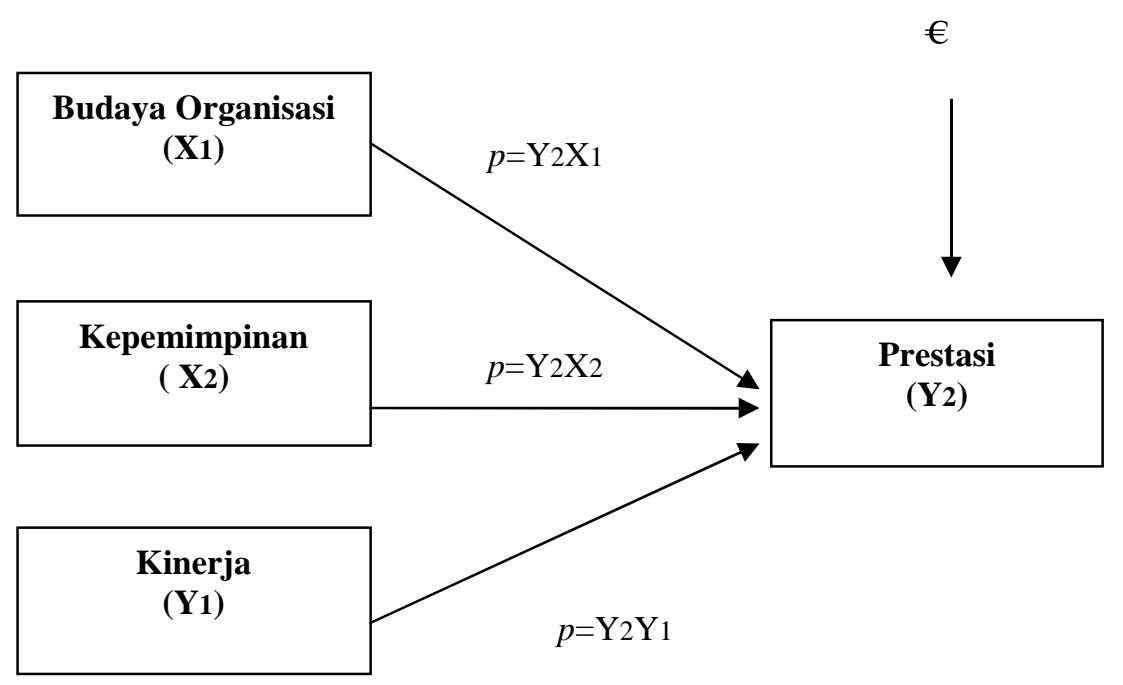

Gambar 2. menunjukan bahwa dari diagram jalur tersebut terdapat 3 buah variabel eksogenus yaitu $\mathrm{X} 1, \mathrm{X} 2$, dan $\mathrm{Y} 1$ dan sebuah variabel endogenus (Y2) serta sebuah variabel residu $\epsilon$. Pada diagram diatas juga menggambarkan bahwa hubungan antara X1 dengan $Y 2$, $\mathrm{X} 2$,Y2 dengan X2 dan Y2 dengan Y1 adalah hubungan kausal, sedangkan hubungan antara X1 dengan X2, X1 dengan $\mathrm{Y} 1, \mathrm{X} 1$ dengan $\mathrm{Y} 1, \mathrm{X} 2$ dengan $\mathrm{Y} 1$ dan masing-masing adalah hubungan korelasional. Bentuk persamaan strukturalnya adalah :

$$
\mathrm{Y} 2=p \mathrm{Y} 2 \mathrm{X} 1+p \mathrm{Y} 2 \mathrm{X} 2+p \mathrm{Y} 2 \mathrm{Y} 1+\epsilon
$$

\section{Rancangan Uji Hipotesis Statistik}

Pengujian secara statistik terhadap variabel bebas yang dipilih memiliki pengaruh nyata atau tidak terhadap variabel terikat, dapat dilakukan melalui uji statistik t dan uji statistik F. Uji statistik $t$ dapat digunakan untuk menguji koefisien regresi dari masing-masing variabel, apakah secara terpisah variabel ke-1 berpengaruh nyata terhadap variabel tidak bebas. Sedangkan uji statistik F digunakan untuk menguji koefisien regresi secara serentak, apakah variabel variabel bebas secara bersama-sama dapat menjelaskan variasi dari variabel tidak bebas. Pengujian hipotesa atau masing-masing koefisien regresi dilakukan dengan uji t dengan hipotesa:

$$
\begin{aligned}
& \text { H0 }: \rho=0 \\
& \text { Ha }: \rho \neq 0
\end{aligned}
$$

Pengujian dengan $t$ hitung adalah sebagai berikut :

$$
\text { Thitung }=\frac{\rho \mathrm{i}-0}{\operatorname{Se}(\rho \mathrm{i})}
$$

Dimana Se ( $\rho$ i) adalah standar error parameter dengan $\rho i$

Kriteria uji :

t hitung $<$ t tabel : gagal tolak $\mathrm{H} 0$

thitung $>\mathrm{t}$ tabel : terima $\mathrm{HO}$

Jika hipotesa nol ditolak, berarti variabel yang diuji berpengaruh nyata terhadap variabel tidak bebas. Sebaliknya jika hipotesa nol gagal ditolak, maka variabel yang diuji tidak berpengaruh nyata terhadap variabel. 
Selanjutnya mekanisme yang digunakan untuk menguji koefisien regresi secara serentak adalah :

$$
\begin{aligned}
& \mathrm{H} 0: \rho 1=\rho 2=\ldots \ldots \ldots \ldots \ldots \ldots . . . \\
& \mathrm{Ha}: \rho \mathrm{k}=0
\end{aligned}
$$

Statistik uji yang digunakan dalam uji $\mathrm{F}$ adalah :

$$
\text { Fhitung }=\frac{\text { SSR } /(\mathrm{K}-1)}{\mathrm{SSE} /(\mathrm{N}-\mathrm{K})}
$$

Dengan derajat bebas $(\mathrm{K}-1),(\mathrm{N}-\mathrm{K})$, dimana :

SSR = jumlah kuadrat regresi

SSE = jumlah kuadrat sisa

$\mathrm{N}=$ jumlah pengamatan

$\mathrm{K}=$ jumlah parameter

Kriteria uji :

Fhitung < Ftabel : gagal tolak H0

Fhitung $>$ Ftabel : terima H0

Jika hipotesa nol ditolak, berarti minimal terdapat satu variabel yang digunakan berpengaruh nyata terhadap variabel tidak bebas. Sebaliknya, jika hipotesa nol gagal ditolak, berarti secara bersama variabel yang digunakan tidak bisa menjelaskan variasi dari variabel tidak bebas. Jika nilai $\rho>0,05$ maka dianggap pada jalur terdapat pengaruh yang signifikan dan Jika nilai $\rho<0,05$ maka dianggap pada jalur tidak terdapat pengaruh yang signifikan.

\section{SIMPULAN}

Berdasarkan hasil penelitian yang dilakukan dapat disimpulkan bahwa: (1) Variabel Budaya Organisasi (X1) berpengaruh positif dan signifikan terhadap variabel kinerja Pengprov Cabor (Y1), dengan nilai sig $=0,002 \leq$ 0,05; (2) Variabel Kepemimpinan (X2) berpengaruh positif dan signifikan terhadap Variabel Kinerja Pengprov Cabor (Y1) dengan nilai sig $=0,038 \leq$ 0,05; (3) Variabel Budaya organisasi (X1) berpengaruh positif dan signifikan terhadap Variabel Prestasi atlet (Y2), dengan nilai sig $=0,002 \leq 0,05$; (4) Variabel Kepemimpinan

berpengaruh positif dan signifikan terhadap variabel Prestasi (Y2) atlet KONI Provinsi Riau, dengan nilai sig = $0,000 \leq 0,05$; (5) Variabel Kinerja Pengprov Cabor (Y1) berpengaruh positif dan signifikan terhadap Prestasi Atlet (Y2) Atlet KONI Provinsi Riau dengan nilai sig $=0,000 \leq 0,05$; dan (6) Dari hasil analisis jalur bahwa variabel Budaya Organisasi (X1) mempengaruhi secara tidak langsung terhadap variabel Prestasi Atlet (Y2) melalui variabel Kinerja (Y1) sebesar 0,157, ini merupakan pengaruh tidak langsung dengan nilai tertinggi dari pengaruh tidak langsung lainnya. Namun pengaruh tidak langsung ini belum cukup untuk mendukung pengaruh Budaya organisasi terhadap peningkaan prestasi atlet, dengan demikian Budaya organisasi baru bisa meningatkan prestasi atlet jika organisasi mampu meningkatkan kinerja Pengprov cabor.

Berdasarkan kesimpulan diatas, maka dapat dikemukakan beberapa saran sehubungan dengan Pengaruh Budaya Organisasi (X1), Kepemimpinan (X2), dan Kinerja Pengprov Cabor (Y1) terhadap Prestasi atlet (Y2) KONI (Komite Olahraga Nasional Indonesia) Provinsi Riau, yaitu : Pertama, Dalam rangka mewujudkan Budaya organisasi yang cocok diterapkan pada sebuah organisasi, maka diperlukan adanya dukungan dan partisipasi dari semua anggota yang ada dalam lingkup organisasi tersebut. Sistem yang dapat membantu menemukan dan merumuskan aspek-aspek penting dari budaya dengan spesifikasi perilaku dan kompetensi yang diberikan untuk menyumbang keberhasilan organisasi, unit, kelompok, atau posisi. Dengan demikian Budaya Organisasi baru bisa meningkatkan Prestasi atlet jika Budaya Organisasi yang diterapkan dirasakan 
mampu meningkatkan kinerja pengprov cabor.

Kedua, Pimpinan harus mempunyai visi dan misi yang jelas, dan penjadi pengayom bagi jalannya organisasi, guna pencapaian tujuan bersama. Dalam mengelola dan mengendalikan berbagai fungsi subsistem dalam organisasi agar tetap konsisten, karena pemimpin merupakan bagian penting dalam peningkatan kinerja pengurus.

Ketiga, peningkatan kinerja Pengurus Cabang Olahraga melalui pelatihan-pelatihan dan penyediaan sarana dan prasarana sebagai pendukung program kerja. Kinerja yang baik adalah kinerja yang mengikuti tata cara atau prosedur sesuai standar yang telah ditetapkan dan memiliki beberapa kriteria agar meningkatkan produktifitas sehingga apa yang diharapkan bisa berjalan sesuai apa yang diinginkan. Untuk itulah pihak manajemen terkait mesti turun langsung kelapangan agar bisa melihat bagaimana menciptakan teknik yang baik serta meningkatkan

loyalitas pengurus terhadap organisasi dan pekerjaannya.

Keempat, untuk pencapaian target prestasi harus dapat merekrut pelatih yang profesional dan berpengalaman. Prestasi olahraga yang tinggi selalu jadi impian oleh setiap atlet. Kemampuan prestasi ini tidak terlepas dari perkembangan yang dicapai dalam bidang ilmu kesehatan dan olahraga, mulai dari pemilihan calon atlet sampai pada metode latihan yang dilakukan dengan berbagai alat bantu yang sederhana sampai dengan kompleks.

Untuk meningkatkan prestasi cabang olahraga diperlukan latihan yang dapat meningkatkan seluruh komponen kondisi fisik karena kemampuan kondisi fisik yang prima sangat menentukan tinggi rendahnya prestasi.

\section{DAFTAR RUJUKAN}

Arif, Muhammad. 2018. Analisis Rekrutmen dan Penempatan Kerja terhadap Kinerja Karyawan pada Hotel Oase. Jurnal Al-Hikmah: Vol. 15 (1): 42-63.

Bafirman, H.B., 2013. Kontribusi Fisiologi Olahraga mengatasi resiko menuju Prestasi optimal. Jurnal Media Ilmu Keolahragaan Indonesia, Vol 3 (1).

Bernardin, R.A. 1993. Human Resource management: Av Experimental Approach. Singapore: McGraw Hill.

Blachard, Ken \& Miller, Mark. 2005. The secret: Rahasia kepemimpinan. Jakarta: PT. Elex Media Komputindo.

Desler, Gary. 2004. Manajemen Sumber Daya Manusia. Edisi-9. Jakarta: PT. Indeks.

Handoko, T. H., 2004. Manajemen Personalia dan Sumber Daya Manusia. Yogyakarta: BPFE.

Hasibuan, H. Malayu SP. 2007. Manajemen Sumber Daya Manusia. Jakarta: Bumi Aksara.

Invancevic, Jhon $\mathrm{M}$, Konopaske $\mathrm{R}$. and Matteson, Michael T. 2007. Perilaku dan manajemen organisasi. Edisi Ketujuh. Jakarta : PT. Erlangga.

Kartono, Kartini. 2008. Pemimpin dan kepemimpinan. Jakarta: PT. Raja Grafindo Persada.

Litbang KONI Pusat. 2004. Struktur Berprestasi Tinggi. Jakarta: Penerbit Pusat Penataran Litbang KONI Pusat.

Mangkunegara, Anwar Prabu. 2005. Sumber Daya Manusia perusahaan. Bandung: Remaja Rosdakarya.

Moeljono, Djokosantoso. 2008. More About Beyond Leadership: 12 Konsep Kepemimpinan. Jakarta: PT. Elex Media Komputindo. 
Monty P. Satiadarma. 2000. Dasar-dasar Psikologi Olahraga. Jakarta : Pustaka Sinar Harapan.

Mulyadi, Dedi, dkk., 2012. Pengaruh Budaya Organisasi Terhadap Kinerja Pegawai pada Dinas Marga dan Pengairan Kabupaten Kerawang. Jurnal Manajemen. Vol.09, No.4.

Paskahandirah Risa \& Kuswardari Istiana, 2012, Hubungan Antara harga diri dan Prestasi belajar Fisika pada Siswa STM, Universitas Setia Budi Surakarta.

Ramdan, Pelana. 2013. Persepsi Atlit Terhadap SDM PPLM tentang Prestasi Atlit, Gladi Jurnal Ilmu Keolahragaan, Vol 7 No.2.

Prawirosentono, Suryadi. 2008. Kebijakan Kinerja Karyawan. Yogyakarta: BPFE.

Priyanto, Dwi. 2008. Statistical Product and Service Solution (SPSS). Yogyakarta: MediaKom.

Rivai, Viethzal. 2003. Kepemimpinan dan Prilaku Organisasi: Edisi Kedua, Jakarta : PT. Raja Grafindo Persada.

Robbins, P. Stephen. 2003. Perilaku Organisasi: Konsep, kontroversi, aplikasi, Jilid 3.. Jakarta: PT Prenhallindo

Sarwono, Jonathan. 2011. Mengenal Path analysis, Sejarah, Pengertian dan Aplikasi, E- Jurnal Ilmiah Bisnis dan Manajemen. Vol 11, No. 2 : 285-296.

Satyawati, Ni Made Ria \& Suartana, I Wayan. 2014. Pengaruh Gaya Kepemimpinan dan Budaya Organisasi terhadap kepuasan kerja yang berdampak pada kinerja Keuangan, E-Jurnal Akuntansi Universitas Udayana 6.1: 17- 32.

Scein, Edgard H., 1997. Organizational Culture and Leadership. San Francisco : Jossey-Bass.
Sedermayanti. 2000. Tata Kerja dan Produktivitas Kerja. Bandung: Mandor Jaya.

Siagian, Sondang P., 2002. Kiat Meningkatkan Produktivitas Kerja. Cetakan Pertama, Jakarta: PT. Rineka Cipta.

Siboro, Christian. 2008. Pengaruh Gaya Kepemimpinan Terhadap Semangat Kerja Karyawan.

Simamora, Henry. 2004. Manajemen Sumber Daya Manusia. Edisi Ketiga. Yogyakarta: BP STIE YKPN.

Soedjono, 2005. Pengaruh Budaya Organisasi terhadap Kinerja Organisasi dan Kepuasan Kerja Karyawan pada Terminal Penumpang Umum di Surabaya. Jurnal Manajemen dan Kewirausahaan. Vol. 7 (1).

Subiantoro, Didik. 2012. Pengaruh Motivasi, kepemimpinan dan Budaya Organisasi terhadap kinerja karyawan pada industri Batik (Studi kasus Kampung Batik Kauman Solo). Jurnal Ilmiah Universitas Bakrie. Vol 1 No. 01.2012).

Sugiyono. 2005. Statistik Untuk Penelitian. Bandung: Alfabeta.

Sujarwo. 2012. Pengaruh Kualitas Pelayanan, Budaya Organisasi dan Motivasi Latihan Terhadap Kepuasan Atlit TC PORDA KONI Kota Depok, Gladi: Jurnal Ilmu Keolahragaan. Vol 6 No.1.

Thoha, Miftah. 2007. Prilaku Organisasi: Konsep dasar dan aplikasinya. Jakarta: PT. Raja Grafindo Persada.

Usman, Husaini. 2006. Manajemen: Teori Praktek dan Riset Pendidikan. Jakarta: Bumi Aksara.

Yukl, Gary. 2005. Kepemimpinan Dalam Organisasi. Edisi kelima. Jakarta: Gramedia. 